Georgetown University Law Center

Scholarship @ GEORGETOWN LAW

2010

\title{
The Rule of Law and Human Dignity: Reexamining Fuller's Canons
}

David Luban

Georgetown University Law Center, luband@law.georgetown.edu

This paper can be downloaded free of charge from:

https://scholarship.law.georgetown.edu/facpub/369

2 Hague J. on Rule L. 29-47 (2010)

This open-access article is brought to you by the Georgetown Law Library. Posted with permission of the author. Follow this and additional works at: https://scholarship.law.georgetown.edu/facpub

Part of the Human Rights Law Commons, and the Legal Ethics and Professional Responsibility Commons 


\section{GEORGETOWN LAW Faculty Publications}

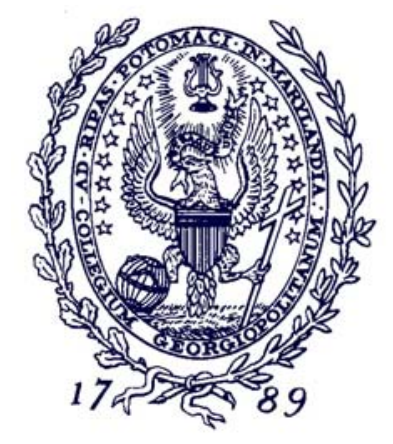

Georgetown Public Law and Legal Theory Research Paper No. 10-29 May 2010

\section{The Rule of Law and Human Dignity: Reexamining Fuller's Canons}

2 Hague J. Rule L. (forthcoming, 2010)

\section{David Luban}

Professor of Law

Georgetown University Law Center

luband@law.georgetown.edu

This paper can be downloaded without charge from:

Scholarly Commons: http://scholarship.law.georgetown.edu/facpub/369/ SSRN: http://ssrn.com/abstract $=1615010$ 


\title{
THE RULE OF LAW AND HUMAN DIGNITY: REEXAMINING FULLER’S CANONS
}

\author{
David Luban*
}

Forthcoming, 2 HAGUE J. RULE OF LAW 29 (2010)

My topic in this brief paper is the connection between the rule of law and human dignity. I want to approach it by discussing the ideas of the American philosopher Lon Fuller, who offered one of the best-known and most elaborate analyses of the rule of law, primarily in his 1964 book The Morality of Law. ${ }^{1}$ Although Fuller's analysis is familiar, his argument that the rule of law inevitably enhances human dignity is not; and there is something to be learned from examining both the strengths and shortcomings of his argument. Before reviewing Fuller's argument and beginning my own, I would like to say a few words about Fuller. Although he is undeniably an important figure in the circle of English-language legal philosophers of the past century, I have the impression that Fuller is underappreciated by legal philosophers even in his home country. Among analytic philosophers he is best known, I think, as H.L.A. Hart's foil in their 1958 debate about legal positivism — and the prevailing view is that Fuller lost the debate, which continues to be read mostly because of Hart. Fuller's more pointed critique of positivism, the 1940 book The Law In Quest of Itself, is virtually unread and-like his book The Anatomy of the Law — was long out of print and is available today only as a high-priced specialty reprint. Fuller is often, and not without justice, criticized as analytically sloppy. Within American law schools, his contracts scholarship remains important, and scholars of alternative dispute resolution recognize him as one of their pioneering theorists; but his jurisprudence is often lumped together with other 'Legal Process' scholarship of the 1950s, less significant than the influential Hart-Sacks teaching materials, and distinctly out of fashion. ${ }^{2}$ His jurisprudence problems of the Grudge Informer and the Speluncean Explorer remain popular and are frequently anthologized; but the noteworthy fact about them is that the popularity of these problems rests in part on how self-contained and readily detachable they are from Fuller's own systematic philosophy. ${ }^{3}$

\footnotetext{
* University Professor and Professor of Law and Philosophy, Georgetown University Law Center, 600 New Jersey Ave. N.W., Washington, D.C. 20001 USA. This paper was originally delivered at the Beijing International Conference on the Rule of Law, 13-14 September 2009, and the $24^{\text {th }}$ World Congress on Legal and Social Philosophy, Beijing 18 September 2009. With these occasions in mind, I have sometimes illustrated my points by reference to the rule of law in China, although examples from other countries could readily be supplied. I am grateful to Danny Priel, Randall Peerenboom, and Joseph Raz for discussions of the paper; and also to two anonymous referees for this journal for suggesting important improvements.

${ }^{1}$ Lon L. Fuller, The Morality of Law, revised ed., 1964). Other landmark analyses of the rule of law are those of John Rawls, A Theory of Justice, $1^{\text {st }}$ ed., 1971, §38, pp. 235-39, and Joseph Raz, 'The Rule of Law and Its Virtue', in: 93 Law Quarterly Review (1977), p. 195, pp. 198-202.

${ }^{2}$ Henry M. Hart, Jr. \& Albert M. Sacks, The Legal Process: Basic Problems in the Making and Application of Law, 2001.

3 Lon L. Fuller, 'The Case of the Speluncean Explorers', in: 62 Harvard Law Review (1949), p. 616; Lon L. Fuller, 'The Problem of the Grudge Informer', in Fuller, The Morality of Law, p. 245. On the Speluncean Explorer, see, e.g., the fiftieth anniversary symposium in 112 Harvard Law Review (1999), pp. 1834-1923.
} 
Although there has been something of a Fuller revival in the last decade or so, it seems to me that Fuller is still a sideshow in analytical jurisprudence. ${ }^{4}$ In an earlier paper, I suggested that one reason for this phenomenon is that Fuller is simply talking about a different subject than that of analytic jurisprudence. ${ }^{5}$ For the latter, the question 'what is law?' is a conceptual one: it asks for necessary and sufficient conditions for a norm to count as legal. Fuller, by contrast, views law not as a system of norms but as a human activity of lawgivers and, especially, lawyers; in one book, he writes 'the word "law" means the life work of the lawyer' ${ }^{6}$ It is, specifically, the enterprise of subjecting human conduct to the governance of rules. ${ }^{7}$ And rather than asking for necessary and sufficient conditions of lawfulness, Fuller inquires into the moral and practical relationships between lawgivers and citizens that allow the enterprise of subjecting human conduct to rules succeed. ${ }^{8}$

Fuller argues that the enterprise succeeds only when the lawgiver respects eight 'canons' that govern the lawmaking enterprise. These constitute his analysis of the rule of law (although Fuller does not use the term 'rule of law' to describe them). To review briefly: they are the canons of generality, publicity, clarity, consistency, feasibility, constancy, prospectivity, and congruence. The rule of law requires that lawmakers conform their handiwork to these canons.

1. Generality: laws must take the form of general rules.

2. Publicity: laws must be published and cannot be secret.

3. Clarity: laws must be comprehensible and not overly vague.

4. Consistency: laws must not contradict one another.

5. Feasibility: it must be possible for people to comply with the law.

6. Constancy: the law must not change too rapidly.

7. Prospectivity: the law cannot be retroactive-it cannot today declare yesterday's lawful behavior unlawful.

8. Congruence: the law must be administered and enforced as it is written.

In his introduction to this symposium, David Shapiro notices that 'if one were unfamiliar with his [Fuller's] other works, one would be hard-pressed to identify his own preferred approach'. Ibid., p. 1839.

${ }^{4}$ On the revival, see, e.g., Willem J. Witteveen \& Wibren van der Burg (eds.), Rediscovering Fuller: Essays on Implicit Law and Institutional Design (1999); or the Special Issue of the journal Law and Philosophy devoted to Fuller: 13 Law and Philosophy (1994), pp. 253-418.

5 David Luban, 'Natural Law as Professional Ethics: A Reading of Fuller', chapter 3 of Luban, Legal Ethics and Human Dignity (2007), pp. 99-130; originally published in 18 Social Philosophy and Policy (2001), pp. 176-205. I have offered additional speculations about the source of Fuller's unwarranted neglect in 'Rediscovering Fuller's Ethics,' in Witteveen \& van der Burg, Rediscovering Fuller, pp. 193-225; also in 11Georgetown Journal of Legal Ethics (1998), pp. 801-29.

6 Lon L. Fuller, The Law In Quest of Itself (1940), p. 3.

${ }^{7}$ Fuller, The Morality of Law, p. 106.

8 So I have interpreted Fuller in Luban, 'Natural Law as Professional Ethics'. I am using the word 'citizen' as convenient shorthand for 'someone governed by the law', not in the technical and legal sense of 'someone who is a national of a particular state'. Legal rules usually apply both to nationals and nonnationals residing in a country; sometimes they apply to non-nationals abroad whose actions have effects within a country. 
Alongside the canons, Fuller announced several provocative theses about them, which have drawn far more criticism than the canons themselves. That is, although commentators typically think that Fuller has indeed offered a satisfying analysis of the rule of law, they object to his claims about what the rule of law amounts to.

First, he labeled his canons the 'inner morality of law', suggesting that they are not simply conditions of efficacy of a legal system, but moral requirements.

Second, he announced that the canons are conditions that make law possible-in other words, that enactments which deviate too much from the canons are not bad law, but rather no law at all.

Third, he described the canons as 'procedural natural law', presumably different from substantive natural law. Where the latter sets moral limits on the content of laws, procedural natural law sets limits on 'the ways in which a system of rules for governing human conduct must be constructed and administered...'. 9

Fourth, and less often noticed than the first three, Fuller claimed that a system of laws satisfying his criteria will enhance human dignity ${ }^{10}$ — and thus, apparently, it amounts to a substantive natural law purchased 'on the cheap' through purely procedural conditions on a legal system.

The first and second of these conditions - the claim that the eight canons amount to an inner morality of law and that they make law possible-provoked sharp criticism from legal positivists. By labeling the canons an 'inner morality', Fuller denies the thesis of the separation of law and morality central to at least certain forms of positivism. By calling them conditions that make law possible, he implies that legal systems that violate the canons, for example by enacting secret or retroactive laws, are not legal systems at all. Positivists respond that Fuller has confused a legal system with a good legal system. A system of secret or retroactive laws may be a terrible idea, but positivists insist that it certainly can be a legal system. Joseph Raz, for example, whose analysis of the rule of law resembles Fuller's, accuses Fuller of confusing the minimum conditions of a legal system with the conditions of an effective legal system. ${ }^{11}$ Following the canons will make a legal system more efficient, but it will not make the laws morally good.

There are responses to these criticisms (and I have explored those responses in my earlier analysis of Fuller's theory ${ }^{12}$ ) but they are not my main subject here. In this paper, I want to take a closer look at Fuller's canons to see what their strengths and weaknesses are as a theory of the rule of law, setting to one side the natural law/positivism debate. I also want to inquire whether in fact the canons do enhance something called 'human dignity'. Thus, my focus is on the third and fourth of Fuller's controversial claims about the canons: that they are a procedural natural law, and that their presence in a legal system enhances human dignity.

${ }^{9}$ Fuller, The Morality of Law, p. 97.

${ }^{10}$ Lon L. Fuller, ‘A Reply to Professors Cohen and Dworkin’, in: 10 Villanova Law Review (1965), p. 655, p. 665.

11 Joseph Raz, ‘The Rule of Law and Its Virtue’, in: 95 Law Quarterly Review (1977), p. 195.

${ }^{12}$ Luban, 'Natural Law as Professional Ethics', pp. 120-26. 
My first conclusion is that Fuller misdescribes his own analysis by labeling it 'procedural', because the canons are in fact mostly constraints on the substance or content of law. I don't mean this as a criticism of Fuller-in my view, his analysis becomes more, not less, persuasive once we stop thinking of it as merely procedural. Second, I shall suggest that once we see how these substantive conditions on laws work, there is an important way in which they do enhance human dignity. But in the end, I think that the conception of human dignity at work in Fuller's claim is too thin to be accepted.

Lastly, I want to say a few words about a fifth thesis of Fuller's about the rule of law-one that is central to his thinking, but remains submerged in The Morality of Law and his account of the eight canons. This is the central role played by practicing lawyers (as distinct from judges or other officials).

\section{The Canons as Substance Not Process}

Let us look more closely at the canons. It should be clear straightaway that the eighth canon — congruence between law and its enforcement-is of a different kind from all the others. The first seven canons are standards for lawmaking. The canon of congruence is different. It focuses on the administration of law, not the making of law. It directs its advice to different people than the first seven canons. Where they set standards for a law-drafter (a legislator or, more generally, a lawyer drawing up a set of rules for an enterprise), the canon of congruence is a standard for the officials charged with enforcing the law and putting its directives into action-police, bureaucrats, judges, and arbitrators. It instructs them to follow the law impartially and with fidelity. For the moment, I want to set the canon of congruence to one side, without denying its importance. I shall return to it at the end of this paper.

It may seem perverse to focus on anything other than the congruence of enforcement and administration with the law. After all, practical discussions of the rule of law focus almost exclusively on whether the authorities actually follow the law, and how to construct institutions so that they follow the law better. Thus, in China, questions about local versus central control of the police, or the role of the Party in law enforcement, circle around whether the police are enforcing the law or the wishes of local officials and cadres. ${ }^{13}$

Of course these are crucial subjects. In my opinion, Fuller does not say enough about congruence. On this subject, it seems to me that Raz's analysis does a far better job of unpacking what congruence entails: an independent judiciary with the power to review actions by other institutions, firm adherence to principles of natural justice (meaning fairness in judicial proceedings), ready access to courts, and honest policing and prosecuting which does not pervert the law. ${ }^{14}$ A full discussion of congruence would examine the practical conditions for securing judicial independence and impartiality, the

\footnotetext{
${ }^{13}$ Here I am relying on Murray Scott Tanner \& Eric Green, 'Principals and Secret Agents: Central vs. Local Control Over Policing and Obstacles to "Rule of Law" in China', in Donald C. Clarke (ed.), China's Legal System: New Developments, New Challenges (2008), pp. 90-116, and the commentary by He Weifang, pp. 117-120. More generally, see Randall Peereboom, China's Long March toward Rule of Law (2002).

${ }^{14}$ Raz, 'The Rule of Law and Its Virtue’, pp. 200-02.
} 
challenges posed by corruption, the role that party politics and affiliation play in the institutions of justice, and so forth. In the final section of this paper, I will suggest that Fuller's understanding of law has much to offer an account of congruence, although Fuller himself does not draw out the implications.

On the other hand, focusing exclusively on congruence runs the risk of ignoring features of lawmaking itself that enhance or undermine the rule of law. Fuller is at his best, I think, in focusing on these features, and they will be my focus as well.

When we examine the remaining seven canons, we see, perhaps surprisingly, that they are mostly substantive constraints on the content of laws. There is nothing procedural about them. To say that laws cannot be vague, or logically inconsistent with each other, are content-based conditions. So too the requirement that the behavior laws demand is feasible for people to perform. ${ }^{15}$ And so too the canon of prospectivity: forbidding, as it does, laws that penalize behavior retroactively, the canon builds a content-based dating requirement into the law.

It might be objected that minimum constraints on the content of laws of the sort described here are not what theorists usually mean when they talk about the substance or content of law. They mean choices among extra-legal values and policies that are embodied in concrete legal standards: pro-market or anti-market, pro-human rights or pro-national security, egalitarian or non-egalitarian, tolerant or intolerant of diversity in religion or in sexual orientation, and so forth. ${ }^{16}$ When Fuller distinguishes his approach from substantive natural law theories, and dubs his own approach 'procedural', he specifically means to deny that his so-called 'inner morality of law' (meaning respect for the eight canons) is substantive in the sense of deliberately embodying a particular set of choices among extra-legal values. ${ }^{17}$

Now in fact, as I shall discuss shortly, Fuller also maintains that the inner morality of law will turn out to be pro-human dignity and pro-freedom. But this is not because lawmakers take dignity and freedom as conscious policy goals that they aim to embody in the law. Rather, they discover that the inner morality of law drives law toward greater freedom and greater respect for human dignity, as though by an invisible hand or cunning of reason, whether or not lawmakers consciously aim at these ends.

When I refer to the canons of clarity, consistency, feasibility, and prospectivity as 'substantive', I do not (therefore) mean that they are substantive in the sense just described, namely demands that the law embody a particular set of moral or public policy choices. Rather, they are substantive in a more literal way: they constrain what laws can say, what requirements can or cannot be included in the corpus juris. A law cannot demand something inconsistent with an existing law that remains in force, or require the impossible, for example that subjects change their behavior retroactively. To be sure, these requirements place quite minimum constraints on the content of law. But they are nevertheless constraints on law's content, and — equally important—-they have nothing to

\footnotetext{
15 One might add that the canons of clarity and consistency are requirements of language and logic, whereas the requirement of feasibility is 'semantic' in the sense of Tarski or Quine-it pertains to the relationship between word and world, between the language of statutes and social and physical reality.

${ }^{16} \mathrm{I}$ am grateful to an anonymous referee for this journal for pressing me on this point.

${ }^{17}$ Fuller, The Morality of Law, p. 96.
} 
do with the procedures through which laws are enacted. If the argument here is correct, Fuller's thesis that the rule of law enhances human dignity must be recast: it is not that procedural requirements can generate substantive requirements, but rather that surprisingly minimal substantive requirements can unexpectedly implicate far-reaching choices about freedom and dignity.

What of the remaining canons? It is less obvious whether the canon of constancy, which requires that the law cannot change too rapidly, is procedural or substantive. On its face it deals with the pace of legal change rather than the content of laws, so that the identical amendment might be proper two years after a law is enacted while it is improper two days after the law is enacted. That sounds procedural. But it is equally possible to recast the canon of constancy as a constraint on the substance of amendments: if a set of legal regulations changes rapidly_as regulations should do when they concern rapidly evolving technologies or volatile financial markets - then the amendments must be minor, or technical, or easily conformed to. Thus the canon of constancy should best be understood as the disjunction of a procedural and a substantive clause: either the law must not change too rapidly (the procedural clause), or the changes must be minor and easily conformed to (the substantive clause).

In my view, the canon of publicity is the only one that is genuinely procedural. It imposes no constraints on the content or wording of laws, demanding only that they be publicly promulgated. Even here, however, the canon generates an important indirect constraint on content. To publicize laws subjects them to scrutiny and opens them to public criticism, political demonstrations, active and passive resistance, and friction. Officials find themselves tempted to enact secret laws when they want to do something boldly outrageous - outrageous enough that they don't want anyone to know they have done it. The requirement of publicity serves to temper the outrageousness of law by making it harder for officials to dodge the political costs of enacting it. ${ }^{18}$ In this way a purely procedural requirement - the only purely procedural requirement among Fuller's canons - may in fact amount to a weak substantive constraint as well. (Weak, because history is replete with truly awful laws that have been publicly promulgated.)

That leaves only the canon of generality, which requires that law take the form of general rules. At first blush, this requirement seems to impose no restriction on the content of laws; in fact, it seems vulnerable to the criticism that it is entirely empty. After all, any legal requirement, even a bill enacted to single out an individual case, can be cast in the logical form of a general rule-either by referring to the individual under a

18 The line of thought here comes from Kant, who proposed as a 'transcendental formula of public law' that 'All actions relating to the rights of others are wrong if their maxims are incompatible with publicity'. Appendix Two to 'Perpetual Peace', 8 Ak. 381, in Kant, Practical Philosophy, Alan Wood (ed.), Mary McGregor (trans.), (1996), p. 347. Kant argued that 'a maxim...that absolutely must be kept secret if it is to succeed and that I cannot publicly acknowledge without unavoidably arousing everyone's opposition to my project, can derive this necessary and universal, hence a priori foreseeable, resistance of everyone to me only from the injustice with which it threatens everyone'. Ibid. For analysis of Kant's 'transcendental formula', see David Luban, 'The Publicity Principle', in Robert E. Goodin (ed.), The Theory of Institutional Design (1996), pp. 154-98. Fuller makes a point similar to Kant's: 'when men are compelled to explain and justify their decisions, the effect will generally be to pull those decisions toward goodness, by whatever standards of ultimate goodness there are'. 'Positivism and Fidelity to Law-A Reply to Professor Hart', in: 71 Harvard Law Review (1958), p. 630, p. 636. 
general description that in fact singles out a single case, or as an exception built into the general law that would otherwise apply. Because general rules often enumerate exceptions, even this one-person bill might be said to satisfy the generality requirement.

But plainly Fuller was not simply talking about the logical form of laws - that (in logician's terms) they fall within the scope of a universal quantifier. The requirement means that a law, as distinct from a one-time directive, uses categories that include numbers of similarly-situated individuals whose identities are not known in advance, or at least are not relevant to the law's purpose, rather than categories that contain only persons whose identities are known, and knowledge of whose identities determines what the law says. ${ }^{19}$ Understood this way, the canon of generality is indeed a content-based requirement.

It might be objected that even though Fuller's canons are largely substantive rather than procedural, the constraints they impose on the substance of laws are too weak to be meaningful. I believe this to be untrue, and will illustrate with an example.

Since September 11, 2001, prosecuting potential terrorists has become a major priority of the U.S. Justice Department. Its primary tool is a broadly-phrased set of statutes prohibiting 'material support' for terrorism and foreign terrorist organizations. These laws declare it a crime to provide any kind of direct material support to terrorists, no matter how minor the support.

But what is material support? As one might expect, 'material support' includes money, weapons, false documents, safehouses, and explosives. But it also includes 'training, expert advice or assistance,... communications equipment, personnel, and transportation'. ${ }^{20}$ How broad are these categories? Is a lawyer defending an organization against terrorism charges providing 'expert assistance' or 'personnel' to it? If the answer is yes, the lawyer risks prison merely for defending her client against accusations of terrorism - exactly what lawyers are supposed to do. What about a teacher giving lessons to nurses who plan to offer medical treatment to Hezbollah in Lebanon? Is that the kind of 'training' that counts as material support for a terrorist organization? What if a militant's uncle gives her a cell phone for her birthday? Is that 'communications equipment'? What about a taxi driver who drives a terrorist to a meeting? Is this minimal form of 'transportation' a crime? Presumably, the law is not aimed at innocuous activities like these. But the language doesn't make that clear. ${ }^{21}$

For over a decade, a group of humanitarian law experts who want to offer training in peacemaking skills to a Turkish militant group (the PPK) has been arguing against the

19 Of course some laws might in fact regulate only a tiny number of individuals. A law governing the licensing requirements for a new, cutting-edge medical specialty might pertain only to the fifty physicians who practice in the specialty. What makes the law 'general' is that their identities don't matter-in other words, they are anonymous to the legislator. One additional point is worth noting: legislation that violates the generality requirement is not always defective. Sometimes, for example, the U.S. Congress enacts a special bill to allow an individual to immigrate to the United States, even though prevailing statutes prohibit it. Congress does this for humanitarian reasons in unusual hardship cases. Such a special bill fails the generality requirement, but may be morally praiseworthy. Fuller's view does not deny that the special bill is morally praiseworthy, but it might deny that it belongs to the rule of law.

2018 U.S.C. §2339A(b)(1).

${ }^{21}$ For these and other examples, see United States v. Al-Arian, 308 F. Supp. 2d 1322 (M.D. Fla. 2004). 
material support statutes in U.S. court. They claim the laws prevent them from engaging in a worthwhile activity, because it is impossible for them to know whether offering the training opens them to prosecution for material support. In half-a-dozen decisions, U.S. courts have agreed, declaring that the terms 'expert advice' and 'personnel' are unconstitutionally vague. The material support statutes are not, in the courts' words, 'sufficiently clear so as to allow persons of ordinary intelligence a reasonable opportunity to know what is prohibited'. ${ }^{22}$

Here, we can see Fuller's canon of clarity in action, defending citizens against one of the most typical abuses of the criminal law. Legislatures often write criminal laws in broad and vague terms. They fear that if they make the terms narrow and precise, clever criminals will find ways to evade the letter of the law. But broad, vague criminal statutes give the authorities enormous discretionary power to repress activities they dislike. The canon of clarity protects against abuse of this sort. In these cases, the canon of clarity imposes a strong, not weak, constraint on the content of criminal laws-strong, in that it rules out one of the favorite strategies legislators use to enhance the power of officials.

So far I have argued that Fuller's eight canons should not be thought of as 'procedural' rules, because in fact they are almost entirely substantive. Thus Fuller's label 'procedural natural law' is quite misleading. In my opinion, Fuller sells himself short. Beginning in the 1970s and 1980s, American legal academics criticized the socalled 'legal process' school of jurisprudence, charging process theorists with two errors: first, with assuming that focus on process rather than substance would be more neutral, more objective, less controversial, and less value-laden, than focus on substantive disputes in the law. In other words, legal process scholars were wrong to argue that even when we cannot agree on what interests the law should protect, we can at least agree on processes of lawmaking and dispute resolution. This view, the critics charged, overlooks the way that substantive assumptions get built into process. ${ }^{23}$ Indeed-and this was the second criticism - the very distinction between substance and process is doubtful, because choices about what processes the law employs often determine the outcomes, and indeed what counts as process in one case is labeled 'substance' in another. ${ }^{24}$ Thus, the critics charged, legal process scholars held a misty, optimistic, and even naïve view that procedure can rise above the fray of controversy and reconcile competing social interests.

I don't want to discuss the merits of these arguments here, because my point is that they simply don't apply to Fuller's eight canons, which are restrictions on the content of law, not on the process of enacting or enforcing it.

22 Humanitarian Law Project v. Mukasey, 552 F.3d 916, 928 (9th Cir. 2009)(quoting Foti v. City of Menlo Park, 146 F.3d 629, 638 ( $9^{\text {th }}$ Cir. 1998)). The opinion in this decision summarizes the earlier rounds of the litigation. The litigation is currently (as of January 2010) pending before the United States Supreme Court, which will determine whether narrowing amendments to the statutes responding to previous rounds of the litigation make the terms of the statute sufficiently clear.

23 For a sophisticated recent version of this critique, see Louis Michael Seidman, Our Unsettled Constitution: A New Defense of Constitutionalism and Judicial Review ( 2001), pp. 144-72.

${ }^{24}$ This is an argument that has been known for eighty years. See, e.g., Walter Wheeler Cook, “"Substance” and "Procedure” in the Conflict of Laws', in: 42 Yale Law Journal (1932-33), p. 333. 
Remember that for Fuller, law is 'the enterprise of subjecting human conduct to the governance of rules'. Legal rules are meant to be action-guiding. ${ }^{25}$ To be more precise about the action-guiding character of legal rules, we must distinguish between primary rules, in Hart's sense, which are meant to guide the action of ordinary citizens, and secondary rules, which are meant to guide the action of the officials who administer the system as lawmakers, law-enforcers, and law-appliers. Fuller meant the former, as the canon of congruence clearly indicates. To call primary rules action-guiding means, first, that people must know what the rules are, and second, that the rules are ones that people can reasonably be expected to follow. Viewed in this light, the point of Fuller's canons becomes clear. Publicity, clarity, and consistency are canons of clear communication. Feasibility and constancy are canons of reasonableness. Prospectivity is both, in that a retroactive law is not communicated adequately to those subject to it, and it is unreasonable to expect someone to conform yesterday to a law that did not exist until today. ${ }^{26}$ The ultimate significance of the canons is that they make it possible to guide actions through rules. In the end, that goal has very little to do with procedure, and a great deal to do with the substance of law.

\section{The Virtue in the Rule of Law}

Fuller believes that demanding clear communication and reasonableness from lawmakers will result in morally better law. Joseph Raz is skeptical. Raz agrees that the canons make law better at accomplishing its own purposes, just as sharpness makes a knife better at cutting. But, he cautions, 'the rule of law also enables the law to serve bad purposes. That does not show that it is not a virtue, just as the fact that a sharp knife can be used to harm does not show that being sharp is not a good-making characteristic of knives. At most it shows that ... it is not a moral good'. ${ }^{27}$

As a conceptual matter, Raz is clearly correct. And Fuller in fact emphasizes the practical efficacy of governance through rules. ${ }^{28}$ But Fuller also believes that the canons push the law away from a certain kind of moral badness, and it is important to see why.

Consider a legal system that lacks the characteristics of clear communication and reasonableness. What is it like to live under such a system? It is, I wish to suggest, to live in constant jeopardy and fear. To be confronted by laws that I cannot obey means that I am always subject to arrest and punishment. To be confronted by laws that I cannot know or understand means that I can remain safe only if I avoid any activity that is even remotely likely to trigger the hostility of the authorities. Such a system transfers an immense amount of discretionary power to the authorities, who can ensnare me or punish me more or less at will.

\footnotetext{
${ }^{25}$ This point is central to Raz's account of the rule of law as well. 'The Rule of Law and Its Virtue', p. 198.

${ }^{26}$ I am taking both the terminology and the argument from Luban, 'Natural Law as Professional Ethics', p. 116.

${ }^{27}$ Raz, 'The Rule of Law and Its Virtue', p. 208.

${ }^{28}$ A sentence that I quoted earlier, which called the canons 'the ways in which a system of rules for governing human conduct must be constructed and administered....' continues: '....if it is to be efficacious and at the same time remain what it purports to be'. Fuller, The Morality of Law, p. 97.
} 
It is a mistake to think of despotic government as lawless. Despots like laws, provided that the level of legal uncertainty is large, so that official discretion is at a maximum and citizens must always be cautious. Despotism thrives by creating a sticky spider web of tangled laws and obscure regulations. Nearly every citizen is in technical noncompliance with some law or other, subject to arrest and prosecution at the whim of the authorities. To return to my earlier example of vague criminal laws, it is hardly surprising to learn that a favorite device of repressive regimes is the broad and vague criminal statute - the statute that makes it a crime to engage in 'anti-social conduct' or 'conduct against the state' or-in the Nazi regime-conduct that runs contrary to 'healthy popular sentiment' (gesunde Volksempfindung). ${ }^{29}$ Laws like these enable officials to prosecute anyone at any time, and citizens who understand this will prefer not to test the limits or annoy the authorities.

Raz is clearly correct that the rule of law is no guarantee of mild government or liberal rights. Obviously, very harsh laws can be promulgated clearly, publicly, prospectively, and so on. But the rule of law does deprive governments of some of their favorite devices of intimidation, namely vague laws, secret laws, retroactive laws, confusing and inconsistent laws, all of which are used to keep citizens cautious and fearful.

This is one reason Fuller believes that the rule of law enhances human dignity. The point is not that the rule of law is logically incompatible with despotic government or harsh laws. ${ }^{30}$ Rather, the point is that the rule of law robs despotism of some of its most characteristic devices, and in this way it is practically incompatible with despotism. Why would repressive governments want to burden themselves by restricting the laws they enact to those permitted by Fuller's canons? It seems overwhelmingly likely that they would not, because their power to intimidate their subjects would diminish.

The connection of this point with human dignity is relatively straightforward. As I understand the concept of human dignity, it is not a metaphysical property of human beings. Rather, it consists in relationships among human beings in which they do not humiliate and degrade each other. Respectful relationships honor human dignity; humiliating relationships violate it; and institutions honor human dignity when they do not humiliate people. ${ }^{31}$ Lawmaking that violates Fuller's canons offends against human dignity by subjecting people to an especially humiliating condition: that of perpetual

\footnotetext{
${ }^{29}$ This notorious general clause appeared in the Gesetz zur Änderung des Strafsgesetzbuchs vom 28. Juni 1935, 1 Reichsgesetzblatt at 839; see 6 BVerGE at 132-222 (1959); Ingo Müller, Hitler's Justice: The Courts of the Third Reich, Deborah Lucas Schneider trans., (1991), p. 74.

${ }^{30}$ To take a clear example: the United States has notoriously harsh criminal sentences, and the sentencing guidelines, originally designed to take away judges' discretion in sentencing, have only made the system harsher by making it difficult for judges to grant downward departures from tough sentences. The Supreme Court has permitted life sentences for petty frauds and life without parole for a first-offense drug possession. All of these sentences are laid out in statutes and guidelines that satisfy all of Fuller's canons. For discussion, see James Q. Whitman, Harsh Justice: Criminal Punishment and the Widening Divide Between America and Europe (2003).

${ }^{31}$ Here I am borrowing the definition of Avishai Margalit, The Decent Society, Naomi Goldblum (trans.), (1996), p. 1. For further elaboration, see Luban, Legal Ethics and Human Dignity, pp. 88-90.
} 
uncertainty and fearfulness because one's fate lies in the hands of official whim, which can choose at will to stigmatize conduct as criminal. ${ }^{32}$

\section{General Rules and Human Dignity}

Fuller has another reason for believing that the rule of law enhances human dignity, but here I have come to doubt the power of his argument.

His argument is a sustained reflection on the idea that law takes the form of general rules - canon one. To understand its significance, we must begin with a distinction that Fuller draws between two forms of governance, rule through laws and rule through managerial directives. ${ }^{33}$ Law operates through general rules, while managers operate through singular directives. ${ }^{34}$ Managerial directives are the best and appropriate form of governance in many settings - think of a traffic policeman directing traffic on a busy intersection, or a military officer giving orders on the battlefield, or a business manager making moment-to-moment decisions on how to get the job done.

Once we notice this, we understand that the rule of law is by no means superior to managerial direction in all settings. But it clearly is better in some settings-specifically, those settings in which the aim of governance is to establish a stable framework of detailed expectations within which people can plan their own affairs and make their own decisions.

Which realms of social life should be governed through legal rules, and which through command-and-control? This is obviously not a question to be settled here-it is, after all, the fundamental question of political economy and institutional design of the last four centuries! China's three-decades-long transition from a planned to a marketoriented economy is a particularly dramatic setting in which to pose the question, but legal philosophy is not the discipline to answer it. The answer will turn on specific practical features of a vast variety of social settings.

Nevertheless, it was Fuller's dominant question, not only in his analysis of the rule of law but also in his broader quest in what he called 'eunomics', the study of basic institutions for ordering a society. Here, I want to focus on one of his assertions: that governance through general rules by itself implies 'a certain built-in respect for human

\footnotetext{
${ }^{32}$ Raz also argues that violations of the rule of law offend against human dignity. Raz, 'The Rule of Law and Its Virtue', pp. 204-05. His argument, centered on the importance of human autonomy, differs from mine, which centers on whether relationships are or are not humiliating.

33 Fuller, The Morality of Law, p. 207.

${ }^{34}$ Raz objects that laws can be particular directives as well as general rules, and in fact '[i]t is humanly inconceivable that law can consist only of general rules and it is very undesirable that it should. Just as we need government both by laws and by men, so we need both general and particular laws to carry out the jobs for which we need the law'. Raz, 'The Rule of Law and Its Virtue', p. 197. He cites the example of a policeman's orders, which clearly are particular directives. But I find it linguistically peculiar and misleading to call the policeman's orders 'laws'. To be sure, they are legally authorized (or at least some of them are). But when the traffic policeman motions a motorist to stop, the motion is not a law. Violating the policeman's commands is illegal, but that is because a general law authorizes the policeman to issue enforceable commands, not because the policeman's command is a law.
} 
dignity ${ }^{35}$ that managerial direction presumably lacks. What does Fuller mean, and is he right?

The basic difference between governance through rules and governance through managerial directives is this: 'The law does not tell a man what he should do...; it furnishes him with baselines against which to organize his life with his fellows'. ${ }^{36}$ Thus 'the view of man implicit in legal morality' is as 'a self-determining agent'. ${ }^{37}$ Rule of law regimes count on citizens to understand and interpret their requirements in particular cases. The manager, by contrast, gives case-by-case directives.

Philosophers, notably Kant and Wittgenstein, have long observed that a general rule cannot incorporate instructions on its own application to particular cases, because the result would be an infinite regress in which each set of instructions needs another set of instructions. ${ }^{38}$ Nor can a general rule enumerate all its own exceptions-it would become too large and unwieldy for our limited computational capacity. With these thoughts in mind, Fuller argues that governance through rules therefore counts on a shared implicit understanding of the scope and application of rules. By this he means that lawmakers and citizens belong to the same interpretive community or (in Wittgenstein's familiar phrases) play the same language games and share the forms of life within which the language games are played.

Obviously, people do quarrel about the meaning of legal rules-otherwise litigation would never involve legal arguments, only factual disputes. Fuller does not deny this. What he means is rather that legal arguments occur against a background understanding of what Fuller calls 'the limit of legal decency and sanity'. ${ }^{39}$ Not just anything counts as a non-frivolous legal argument, and the range of possible interpretations of the law is always quite limited. Rule through law counts on citizens to understand what the legal rules require of them in the overwhelming majority of cases. Fuller uses the term 'implicit law' to refer to the background understandings that make it possible to agree broadly on the limits of legal decency and sanity. ${ }^{40}$ Unless legislators could count on this stable background of implicit law, governance through general rules would be impossible.

Furthermore, governance through rules counts on citizens to self-monitor and comply with rules in a way that governance through directives does not. Putting these

\footnotetext{
${ }^{35}$ Lon L. Fuller, ‘A Reply to Professors Cohen and Dworkin', in: 10 Villanova Law Review (1965), p. 655, p. 665.

${ }^{36}$ Lon L. Fuller, 'Human Interaction and the Law', in Fuller, The Principles of Social Order: Selected Essays of Lon L. Fuller, Kenneth I. Winston (ed.), (1981), p. 234.

${ }^{37}$ Fuller, The Morality of Law, pp. 162, 166.

38 Immanuel Kant, Critique of Pure Reason, Norman Kemp Smith trans., (1929), pp. 177-78, A132/B171 A134/B174; Critique of the Power of Judgment, Paul Guyer (ed.), Paul Guyer \& Eric Matthews (trans.), (2000), p. 57, 5Ak. 169; Ludwig Wittgenstein, Philosophical Investigations, $3^{\text {rd }}$ ed., G. E. M. Anscombe (trans.), (1953), §43, as well as the passages in this work and Remarks on the Foundations of Mathematics, G. H. von Wright, Rush Rhees, G.E.M. Anscombe (eds.), G.E.M. Anscombe (trans.), (1956) indexed under 'Rule, following a'.

${ }^{39}$ Lon L. Fuller, The Anatomy of the Law (1968), p. 90.

${ }^{40}$ For more detailed discussion, see Gerald J. Postema, 'Implicit Law', 13 Law \& Philosophy (1994), p. 361.
} 
two points together, governance through rules involves greater trust than governance through directives. I take it that this is what Fuller means when he talks about 'the view of man in legal morality' as self-determining agency_and why he concludes that rule by law respects human dignity in a way that rule by managerial directives does not.

But even if lawmakers trust citizens to understand and comply with rules, that trust falls far short of respect for the dignity of citizens as I have described it: a relationship in which the citizen is not humiliated. The limited form of reciprocity needed for governance through rules is very weak, and it tolerates social relationships marked by radical subordination of one person by another. Masters and slaves share a language and a form of life; the trouble is that the form of life they share wholly degrades the slave.

The problem is that Fuller understands human dignity in an overly libertarian way. ${ }^{41}$ He celebrates the autonomy of citizens to plan their affairs around legal rules without asking whether legal autonomy suffices to guarantee human dignity. Rather obviously, it does not. Private oppression, domestic violence, workplace exploitation, and radical inequality are evils that legal autonomy will not cure. Indeed, legal autonomy may contribute to them by insulating private power from the state. State intrusion can protect people as well as oppress people, and decent states will intervene to establish the conditions in which people can live in dignity, that is, without enduring systematic humiliations. $^{42}$

\section{The Role of Lawyers in the Rule of Law}

One of the other central features of Fuller's writing on the rule of law is the significant role he assigns to lawyers. This is a particularly rich subject, too large for me to fully explore here. ${ }^{43}$ Instead, I shall simply tick off some crucial points. As we shall see, lawyers turn out to play a central role in securing canon eight, the congruence between law and its administration.

First, on Fuller's understanding law appears anywhere that people attempt to subject conduct to the guidance of rules. State-made law is only one legal setting. A private club or society is also a lawmaker, if it governs itself through rules. A private contract between two parties is likewise law, if the parties set up rules and procedures for contract compliance and dispute settlement. Thus, when Fuller speaks of contract law, he means not only the laws governing contract formation and enforcement, but also the laws that the contract itself creates. Fuller is a legal pluralist rather than a statist.

Second, Fuller emphasizes that writing rules that fulfill the eight canons and accomplish their other purposes is a difficult technical accomplishment. Legal drafting is

\footnotetext{
${ }^{41}$ Consider the similarity between Fuller's ‘self-determining agency' and Hayek’s description of the rule of law quoted by Raz, 'The Rule of Law and Its Virtue', p. 195: 'government in all its actions is bound by rules...-rules which make it possible to foresee with fair certainty how the authority will use its coercive powers in given circumstances, and to plan one's individual affairs on the basis of this knowledge'. Hayek's definition focuses largely on the canon of congruence, and I think Fuller's definition is richer than Hayek's. But both emphasize the central libertarian value of planning one's own affairs.

42 This is an important theme in the work of Robin L. West. See, e.g., Re-Imagining Justice: Progressive Interpretations of Formal Equality, Rights, and the Rule of Law (2003); Caring for Justice (1999).

43 I have done so at greater length in two other papers: Luban, 'Natural Law as Professional Ethics' and 'Rediscovering Fuller's Legal Ethics'.
} 
not easy; it requires specialized training in a complex technical skill. Fuller aptly likens it to the skills of an architect, who studies the client's ideas, tastes, needs, and budget, and turns them into a set of blueprints and instructions. For Fuller, the lawyer is 'an architect of social structure'. ${ }^{44}$ As such, the task of lawyers is to understand complex human and social problems and translate them into rules_-paradigmatically, the terms of a contract - that enable the parties to conduct their business with the least friction possible.

Third, when lawyers act as architects of social structure, they are lawmakers, subject to the canons defining the rule of law. This point follows as a consequence of the first two. Lawmaking occurs on many levels of society other than that of the state. It occurs, in fact, whenever people subject conduct to the governance of rules. Thus whoever draws up those rules, whether they are legislation, administrative regulation, partnership agreements, or - to borrow Fuller's example-a contract between a paper company and a chain of gas stations to supply two years' worth of paper towels for the gas station bathrooms. $^{45}$

Though Fuller does not dwell on the point, the fact that private lawyers involved in transactional practice in fact write much of the law makes the bar one of the most important institutions of civil society. The rule of law is always a rule of lawyers, andas Tocqueville emphasized-lawyers become an important countervailing power to the state, tempering state power with fussy legal formalities. The role of lawyers mediating between citizens and the state is a tremendously important one. It is not always a positive one, because lawyers acting on behalf of powerful private actors can amplify their power over citizens in unjust ways. But it seems impossible to attain the rule of law without a healthy, independent bar. To the extent that Fuller emphasizes these constructive roles of practicing lawyers and builds them into the fabric of his jurisprudence, his work should be celebrated. Other philosophers of law typically examine the law from the point of view of judges deciding cases (Ronald Dworkin, for example, calls legal philosophy 'the general part of adjudication, silent prologue to any decision at law, ${ }^{46}$ ); or the point of view of legislators, a standpoint championed in recent years by Jeremy Waldron; ${ }^{47}$ or, especially among philosophical anarchists asking whether we actually owe any obligations to obey the law, the point of view of ordinary citizens. Fuller is unique in asserting the primacy of practicing lawyers in our understanding of what law is.

I would like to conclude with two points about the role of lawyers in the rule of law that in my view Fuller neglects. First, he underemphasizes another crucial role that lawyers play, as interpreters and counselors to client about the meaning of the law. ${ }^{48}$ This omission is unfortunate, given the emphasis that he rightly places on citizens as selfmonitoring interpreters and compliers with the law. The law of modern states is complicated, and in fact in many cases it is barely comprehensible to ordinary people.

\footnotetext{
44 See Lon L. Fuller, 'The Lawyer as an Architect of Social Structure’, in The Principles of Social Order, p. 269.

45 Ibid., p. 265.

46 Ronald Dworkin, Law's Empire (1986), p. 90.

47 See, e.g., Jeremy Waldron, The Dignity of Legislation (1999).

48 Fuller discusses the counseling role in one place, but the discussion is brief, amounting to two paragraphs. Lon L. Fuller \& John D. Randall, 'Professional Responsibility: Report of the Joint Conference’, 44 American Bar Association Journal (1958), p. 1159, p. 1161.
} 
The lawyer is one who explains the law's requirement, and makes possible the selfmotivated compliance that Fuller emphasizes. Lawyers are particularly suited to this role because, in most countries, they are educated in a uniform legal language, and trained using more-or-less uniform textbooks and pedagogy into similar modes of reasoning and case-analysis-what in U.S. law schools is called 'thinking like a lawyer'. These are material conditions for 'implicit law'.

The importance of the legal counselor's role became especially vivid in the United States in the past decade through two sets of events: the corporate frauds and scandals associated with Enron and other major corporations at the beginning of the decade, and the revelations of U.S. government torture in the wake of Abu Ghraib. In the latter case, highly placed government lawyers whose job was to advise the President about his legal obligations wrote 'torture memos' approving brutal interrogation tactics, using arguments that most observers found doubtful or even frivolous. In the former cases, lawyers proved all to eager to write opinion letters blessing crooked transactions. In all these cases, the counselor's role was submerged under the advocate's role. Although Fuller was one of the first writers on legal ethics to draw the distinction between the roles of advocate and advisor, he did not sufficiently appreciate that the independent advisor's role is central to the rule of law. ${ }^{49}$

This takes us back to Fuller's canon of congruence-his requirement that law must be administered as it is written, call it a congruence between the law in books and the law in action. By neglecting the role of lawyers as counselors, Fuller missed an opportunity to make a larger contribution to elaborating what it takes to realize congruence in practice. Writers on the rule of law often view congruence as principally a requirement on judges, police, and other enforcement officials. But in a modern industrial society, officials cannot and should not monitor everything. Congruence between, say, business practices in a large corporation and spottily-enforce regulatory requirements will be accomplished only if lawyers, in their roles as compliance counselors, fill the gap. A lawyer-centered jurisprudence like Fuller's offers the most promising invitation to understanding the nature of congruence-so central to the rule of law-but Fuller himself did not fully take up his own invitation.

Second, once we understand Fuller's point about the centrality of lawyers to the rule of law, the importance of access to low-cost legal services becomes clear, although it is a point that to my knowledge Fuller never mentions. He is hardly alone in this: virtually no philosophers of law have paid attention to access to legal services as a central feature of the rule of law. ${ }^{50}$

Unfortunately, the requirement of access lies in considerable tension with marketbased distribution of legal services, and thus indirectly with the independence of the

\footnotetext{
49 On this subject the work of Robert Gordon is crucial. See, e.g., Robert W. Gordon, 'The Independence of Lawyers', in: 68 Boston University Law Review (1988), p. 1 and Gordon, 'A New Role for Lawyers? Corporate Counsel After Enron', in: 35 Connecticut Law Review (2003), p. 1185.

50 There are exceptions. I have discussed the issue in David Luban, Lawyers and Justice: An Ethical Study (1988), pp. 237-89. See also Alan Wertheimer, 'The Equalization of Legal Resources', in: 17 Philosophy \& Public Affairs (1988), p. 303. For recent discussion, see Deborah L. Rhode, Access to Justice (2004).
} 
bar. ${ }^{51}$ Those who can afford lawyers have them; those who cannot afford lawyers are frozen out of the legal system, and ultimately out of the rule of law. It may be, then, that two conditions of the rule of law - the independence of the bar, and the availability of legal services-are incompatible with each other. If so, it would show that the fullfledged rule of law, which Fuller once called 'the life work of the lawyer', will inevitably remain an elusive idea.

${ }^{51}$ Among the firsts writers to notice this tension is Mark J. Osiel, 'Lawyers as Monopolists, Aristocrats, and Entrepreneurs’, in: 103 Harvard Law Review (1990), p. 2009, pp. 2013-22. 